\title{
INTERLOCKING DIRECTORSHIPS AND THE CLAYTON ACT AFTER 35 YEARS
}

\author{
VICTOR H. KRAMERT
}

"Morgan Firm OUt of Thirty Boards" was the front-page headline in the New York Times for January 3, 1914. In a public statement, Mr. J. P. Morgan said:

"The necessity of attending many board meetings has been so serious a burden upon our time that we have long wished to withdraw from the Directorates of many corporations. Most of these Directorships we have accepted with reluctance, and only because we felt constrained to keep in touch with properties which we had reorganized or whose securities we had recommended to the public, both here and abroad. An apparent change in public sentiment in regard to Directorships seems now to warrant us in seeking to resign from some of these connections.

"Indeed it may be, in view of the change in sentiment upon this subject, that we shall be in a better position to serve such properties and their security holders, if we are not Directors. We have already resigned from the companies mentioned, and we expect from time to time to withdraw from other boards upon which we feel there is no special obligation to remain." 1

The Morgan announcement created a sensation ${ }^{2}$ and was heralded as an "epoch-making" event. ${ }^{3}$ Colonel House wired President Wilson that Morgan's action was "an indication that big business is preparing to surrender unconditionally." 4

Wilson himself, in his message to Congress on January 20, 1914, stated that "the antagonism between business and Government is over." 5 Nevertheless, he persisted in his recommendation that laws be enacted

$\dagger$ Trial Attorney and Assistant Chief, Trial Section, Antitrust Division, United States Department of Justice. The opinions expressed in this article do not necessarily reflect the views of the Department of Justice.

1. New York Times, Jan. 3, 1914, p. 1, col. 1. Samuel Untermeyer, who had been counsel for the Pujo Committee, was quick to point out that despite the resignations by some partners, others remained on the same boards. Id., p. 2, col. 3. In addition, the thirty resignations included several from subsidiary corporations. Nevertheless, after the resignations there was no longer any Morgan partner as a director of the New York Central, the New York, New Haven and Hartford, or American Telephone and Telegraph. Id., p. 1, col. 1 .

2. As an amusing illustration of the public excitement and importance attributed to the Morgan announcement, see Meaning of the Morgan Withdrazvals, 48 LiteranY DIGEST 89 (1914), particularly the cartoons at 90-91.

3. Philadelphia North American, quoted in 48 Literary Digest 89, 92 (1914).

4. BAKER, 4 WOODROW WILSON 369 (1931).

5. Id. at 370 . 
“. . . which will effectually prohibit and prevent such interlockings of the personnel of the directorates of great corporationsbanks and railroads, industrial, commercial, and public-service bodies-as in effect result in making those who borrow and those who lend practically one and the same, those who sell and those who buy but the same persons trading with one another under different names and in different combinations, and those who affect to compete in fact partners and masters of some whole field of business." o

Section 8 of the Clayton Act was the legislative response to the Presidential recommendation. Although it fell pitifully short of his objectives, Congress believed that it had carried out his recommendations. ${ }^{7}$ In their reports on the bill, the Committees of both the House and the Senate said:

"The idea that there are only a few men in any of our great corporations and industries who are capable of handling the affairs of the same is contrary to the spirit of our institutions. . . . The truth is that the only real service the same director in a great number of corporations renders is in maintaining uniform policies throughout the entire system for which he acts, which usually results to the advantage of the greater corporations and to the disadvantage of the smaller corporations which he dominates by reason of his prestige as a director and to the detriment of the public generally." 8

Section 8 differentiates interlocking directorships in banks and common carriers from those in all other corporations engaged in interstate commerce. $^{9}$ That portion of the Section relating to interlocking directorships in all but the two excepted classes provides in part as follows:
". . . [N]o person at the same time shall be a director in any two or more corporations, any one of which has capital, surplus, and undivided profits aggregating more than $\$ 1,000,000$, engaged in whole or in part in commerce, . . . if such corporations are or shall have been theretofore, by virtue of their business and location of operation, competitors, so that the elimination of competition by agreement between them would constitute a violation of any of the provisions of any of the antitrust laws." 10

6. See Sen. Rep. No. 698, 63rd Cong., 2d Sess. 14 (1914), quoting this part of the President's message.

7. H.R. REP. No. 627, to accompany H.R. 15657, 63rd Cong., 2d Sess. 18 (1914); Sen. Rep. No. 698, 63rd Cong., 2d Sess. 14 (1914).

8. Id. at 16. See the identical language in H.R. Rep. No. 627, 63rd Cong., $2 d$ Sess. 19-20 (1914).

9. Section 10 of the Clayton Act deals with interlocking directorships in common carriers.

10. This portion of Section 8 was passed in substantially the same form as in the bill introduced by Mr. Clayton with the significant exception that a provision in the original bill making a violation a misdemeanor punishable by fine or imprisonment was omitted. 
Consideration of the problems of interpretation arising out of the quoted portion of Section 8 will suggest some of the shortcomings of the statute. While the section raises several minor problems of construction, ${ }^{11}$ the principal questions arise out of the meaning to be given the clause, "so that the elimination of competition by agreement between them would constitute a violation of any of the provisions of any of the antitrust laws." Was this clause intended as a limitation on the preceding word "competitors" so as to render unlawful only those interlocking directorships between corporations that compete to a "substantial" degree? Or is any amount of competition, however slight, enough to outlaw an interlocking directorship?

The problem is accentuated as a result of the growth and diversification of the production of many of the large manufacturing corporations. An example may serve to illustrate. $X$ Company, whose principal lines are in the heavy chemical industry, also produces automobile carburetors. In $1947, X^{\prime}$ 's carburetor sales, valued at $\$ 1,500,000$, constituted less than three per cent of its total sales, and less than two per cent of the total carburetor industry sales. $X$ has on its board a Mr. Jones who also serves on the board of $Y$, an automobile parts manufacturer. Y's sales of carburetors were $\$ 15,000,000$ in 1947 , or less than twenty per cent of the industry total. $Y$ 's principal line was automobile transmissions, its sales amounting to $\$ 40,000,000$ in 1947 . The dollar value of $Y$ 's carburetor sales appears to be substantial although they do not constitute a large percentage either of $Y^{\prime}$ 's total sales or total sales by the carburetor industry. Is Jones violating Section $8{ }^{12}$

One view has it that the "so that . . ." clause is merely explanatory

Section 11 of the Act gives various administrative agencies power to enforce the section by administrative orders and Section 15 gives the Attorney General concurrent jurisdiction to bring suits in equity in the district courts to prevent and restrain violations of the Section.

11. For example, does the Section apply to directorships in two parent companies cach of which has a wholly-owned subsidiary where the subsidiaries are in competition but not the parents? Where the major policies of the subsidiaries are dictated by the parents, it would seem that there is a strong case for holding the directorships unlawful. Sce Douglas and Shanks, Insulation From Liability Through Subsidiary Corparations, 39 YALE L. J. 193 (1929); and see Anderson v. Abbott, 321 U.S. 349, 362 (1944).

12. Assuming that he is, are either of the corporations which elected him to its board also violating Section 8 ? In any event, they can probably be named as defendants and an injunction obtained against one of them prohibiting it from allowing Jones to continute to serve on its board. See Section 11 of the Act giving the Federal Trade Commission authority to enforce compliance with Section 8 and containing the following language:

"If . . . the commission ... shall be of the opinion that any of the provisions of said sections [including Section 8] have been or are being violated, it . . . shall issue ... an order requiring such person to ... rid itself of the directors chosen contrary to the provisions of Sections . . . 8 of this Act. . . ."

"Person" is defined by Section 1 of the Clayton Act to include corporations. 
of existing law; i.e., that agreements between competitors to eliminate competition do violate the antitrust laws. ${ }^{13}$ Those of the contrary view contend that not all such agreements violate the antitrust laws. An agreement resulting in a merger of two competing concerns, for example, does not necessarily violate Section 1 of the Sherman Act. On the other hand, if Congress had intended Section $S$ to ban interlocking directorships only in corporations that could not combine without violating the antitrust laws, it would have been far simpler to join Section 7 , dealing with corporate combinations, with Section 8 , or to insert the word "substantial," which Congress had used in Section 7, before the word "competitors" in Section $8 .{ }^{14}$

Taking the "so that . . ." clause at its face value, a strong argument can be made that if the corporations in which the directorships are held could not lawfully agree upon prices, they may not lawfully have interlocking directors. Such an agreement would eliminate competition between them. Since price-fixing agreements are now unlawful per se regardless of the amount of commerce affected, ${ }^{15}$ this interpretation renders the "so that . . ." clause practically meaningless as a limitation upon the word "competitors." It seems probable nevertheless that the courts will sustain an interpretation of the Section which gives little or no weight to the amount of competitive commerce involved. This view is influenced by recent Supreme Court opinions emphasizing that it is the character of the restraint, not the amount of commerce affected by it that is the factor determining illegality under the antitrust laws. ${ }^{16}$

13. One difficulty with this interpretation is that it neglects the words, "any of the provisions of any of the antitrust laws."

14. That paragraph of Section 8 dealing with interlocking directors in banlis as originally passed in 1914 made unlawful interlocking directorships in two or more banks over a prescribed size without regard to whether the banks were competitors. 38 STAT. 732 (1914). It was amended in 1916 by empowering the Federal Reserve Board to authorize a director of a member bank to be "a director . . . of not more than two other banks, ... if such other bank . . . is not in substantial competition with such member bank." 39 STAT. 121 (1916). It can be argued that the use of the "substantial competition" test in a bill relating to interlocking directorships in banks passed soon after the Clayton Act indicates a Congressional awareness of the problem and a deliberate decision to avoid the "substantial competition" test as applied to interlocking directors in industrial corporations. It also may be argued that if Congress had intended the "substantial competition" test to apply to interlocking directors in industrial corporations, it would not have been necessary expressly to exempt interlocking directorships in competing corporations where each has assets of less than one million dollars. It is highly unlikely that competition between two corporations engaged in interstate commerce having assets of less than a million dollars could be "substantial."

15. United States v. Socony-Vacuum Oil Co., 310 U.S. 150 (1940).

16. E.g., United States v. Yellow Cab Co., 332 U.S. 218, 225 (1947); International Salt Co. v. United States, 332 U.S. 392, 396 (1947). In the International Salt ease, a tying clause restraining the sale of only $\$ 500,000$ of salt annually was held to violate Sec- 
Such an interpretation would give some real content to the Section, but not enough to make it adequate to cope with the problem which it attempted to treat. ${ }^{17}$ The objectives of Section 8 as disclosed by Wilson's message and the Committee reports quoted above were to reduce the number of directorships held by one person in order (1) to eliminate positions of conflicting trusts, (2) to induce directors to so concentrate their responsibilities as to give them time to direct, (3) to create more opportunities for others to rise to positions of prominence, and (4) to prevent the use of interlocking directorships as a means of eliminating competition. Yet the prohibitions of the Section achieve the first three objectives only as incidental results produced by its prohibition of interlocking directorships among competitors. And even in that limited sphere it has failed to achieve its objectives, not only because it deals only with directorships in competing corporations and gives no consideration to other kinds of interlocking directorships that may eliminate competition, but also because it was not, until recently, enforced.

The Federal Trade Commission has issued no cease and desist orders under Section 8 of the Clayton Act. ${ }^{18}$ The Department of Justice has instituted three suits in which violations of Section 8 have been charged. ${ }^{19}$ Either because of resignations by the directors sued, or because of entry of a consent decree, none of these cases ever came to trial. Suits have been filed by private parties claiming to have been damaged by interlocking directorships, but apparently none has ever been decided on the merits. ${ }^{20}$

On October 11, 1947, the Attorney General announced that the Department of Justice had conducted a survey of interlocking directorships held by some 10,000 persons in 1600 leading corporations. Of

tion 1 of the Sherman Act and Section 3 of the Clayton Act, thus apparently overruling sub silentio United States v. United Shoe Machinery Co., 247 U.S. 32 (1918); cf. United Shoe Machinery Corp. v. United States, 258 U.S. 451 (1922).

17. Samuel Untermeyer, writing in April 1914 while the bill was before Congress, urged that it be changed radically. He thought that the Section "strikes only at the form and does not reach the substance of the greatest existing evil in corporate management. ... The difficulty in solving this problem is not on the point of Interlocking Directorates. It is in the interlocking control that the vice lies, whether evidenced by identity of stockholdings, through voting trust, dummy directors, or otherwise." Untermeyer, Completing the Anti-Trust Programme, 199 North American Review 528, 529 (1914). Mr. Nolson who filed minority views in the House of Representatives with respect to the Clayton Act, a month after Untermeyer's article, made similar criticisms. Sce H.R. Rep. No. 627, 63rd Cong., 2d Sess. 8 (1914).

18. See Means, Interlocking Directorates in 8 Excyc. Soc. Scr. 148, 151 (1932). No orders have been issued since the Means article was written.

19. See The Federal Antitrust Laws ( $\mathrm{CCH}$ 1949) 142 (Case \#316 against Rand Kardex Bureau, et al.), 149 (Case \#346 against General Outdoor Advertising Co., ct al.), 167 (Case \#408 against William G. Mather, et al.).

20. See, e.g., National Supply Co. v. Hillman, 57 F. Supp. 4 (W.D. Pa., 1944); Hawaiian Airlines, Ltd. v. Trans-Pacific Airlines, Ltd., 78 F. Supp. 1 (D. Haw., 1948), rev'd, 174 F.2d 63 (9th Cir. 1949). 
this group there were said to be approximately 1500 who held directorships in more than one concern. The Attorney General announced that most of those persons holding directorships in violation of Section 8 had resigned without contest.

Articles in the public press have revealed the resignations of several directors from the boards of two corporations and have attributed them to the Department's program for enforcement of Section 8 . One instance is the resignation of three directors in General Electric who were also directors in competing corporations including United States Steel Corporation. ${ }^{21}$ Another instance was the resignation of several directors from the board of General Steel Castings Corporation because of their directorships in Baldwin Locomotive Works and American Steel Foundries. ${ }^{22}$

The Department of Justice's extra-judicial procedure for wholesale enforcement of Section 8 is a novel antitrust enforcement technique. It has been customary to correct alleged violations by instituting lawsuits. But if enforcement by administrative persuasion accomplishes the objectives of the statute, that method would seem to be not only in the public interest but also in the interests of the persons whose directorships are questioned since it gives them an opportunity to resign without publicity and its attendant unpleasantness. Doubtless this technique could not be used with success in correcting other types of antitrust violations where the relief sought is highly complex. In Section 8 matters, the relief desired is simple and specific: resignation from all but one of the boards of the competing corporations.

Enforcement of Section $\delta$ of the Clayton Act can be at least temporarily upsetting to the business community. For over 30 years virtually no attention has been paid to the Section by most corporations. Some boards, such as that of General Steel Castings Corporation, have had to be reconstituted as a result of recent enforcement.

In addition, the program of enforcement may encourage institution of stockholders' actions attacking the legality of directorships. Management itself has used Section $\&$ to remove directors representing "undesirable" minority interests. ${ }^{23}$

While Section 8 has been revitalized at least to the extent of the vital capacities of its limited prohibition against interlocking directorships among competitors, most of the supposed evils it was designed

21. See New York Herald Tribune, March 23, 1949, p. 36, col. 3.

22. See the feature article by Robert P. Vanderpoel, Financial Editor, in the Chicago Herald-American, Máay 8, 1948.

Standard Corporation Records, March 16, 1950, reported that C. H. Kreienbaum had resigned from Harbor Plywood Corporation "because of notice from the Department of Justice, Anti-Trust Division that his membership on the board violated provisions of the Clayton Anti-Trust Act."

23. See National Supply Co. v. Hillman, 57 F. Supp. 4 (W.D. Pa., 1944). 
to eliminate remain. A survey made recently of the directorships of the thousand largest United States manufacturing corporations discloses that there are approximately 1000 persons who hold more than one directorship among these concerns. ${ }^{24}$ There are about 32 men who hold five or more. Of these 32,20 are bankers, about evenly divided between commercial banks and investment banking houses. The 32 men together hold one or more directorships in about 160 of the top thousand manufacturing corporations and in over 85 non-manufacturing corporations. The partners in two leading investment banking housesLehman Brothers and Goldman, Sachs \& Co.- hold directorships in 35 and 29, respectively, of the top thousand manufacturers and the leading retailing corporations. The directors of J. P. Morgan \& Co., Inc. (the banking corporation) hold an even twenty directorships in the top thousand. These 20 corporations had total assets in 1946-47 of over eight billion, four hundred million dollars. This does not include these same directors' directorships in three Class A railroads having combined total assets of $\$ 3,735,000,000$. One of these roadsmirabile dictu-is the New York Central from which all Morgan partners proclaimed their withdrawal in $1914 .{ }^{25}$

The same bank frequently has partners or directors on the boards of competing corporations. For example, Lehman Brothers has one partner on the board of Fox and another on the RKO board (two of the five major moving picture producers); Goldman Sachs has a partner on the board of Cluett, Peabody and another on the board of Manhattan Shirt (the two largest men's shirt manufacturers); one Morgan director is on the board of Kennecott Copper and another on the board of Phelps Dodge, two of the three largest copper companies. Since, in these examples, the same partner is not on the board of more than one competitor, it would seem that their directorships are not in violation of Section 8. Nevertheless, this is the very evil that Congress was apparently striving in Section 8 to correct. ${ }^{26}$

It would seem inevitable that in serving the interests of the banking firm in which the partners are primarily interested these directors would consult each other regarding the activities of the competitors

24. All of the material in this paragraph is based upon Poor's Register of Directors and Executrves (1948) ; Moody's Manual of Investurents (Industrials, Railroads, Banks-Insurance-Real Estate-Investment Trusts) (1947); and U.S. Dcp't of Comm., 1000 Largest Manufacturing CoRporations (1947).

25. See note 1 supra.

26. Of course, the Government can, under the Sherman Act, attack these directorships if it can prove that they have been used to eliminate competition or otherwise restrain trade. Compare the suit filed in 1947 in the Southern District of New York under tho Sherman Act against the leading investment bankers in which it was alleged that the defendants utilized their positions as directors to encourage mergers. United States $v$. Morgan, et al., Complaint filed S.D.N.Y. October 30, 1947, Civil Action No. 43-757, par. $44 \mathrm{E}(1)$ and $\mathrm{G}$. 
in which each is a director. The decisions that each makes as a director would seem inevitably to be influenced by the common interest of all in the investment banking firm. The result insofar as the industrial competitors are concerned must often be to effect a uniformity of policies. But Section 8 apparently does not cover the situation. ${ }^{27}$

It would even seem lawful under Section $S$ to designate a minor employee of a corporation to sit on the board of a competitor so long as the employee is not a director of the company by whom he is employed. Such a directorship might be declared unlawful under Section 8 , but probably only if it were shown that the employee was in fact a dummy who acted only upon the advice of his director-employer. And any attempt to use the dummy director device to avoid further violations of Section 8 after a court trial would, perhaps, be ineffective. An injunction might be obtained, in language broader than that of the Act, so as to prevent a representative of the defendant from serving in his place. ${ }^{28}$

That this means of avoiding or evading Section $\delta$ is not hypothetical is indicated by the change made in the board of General Steel Castings Corporation after the Department called its attention to Section 8 of the Clayton Act.29 There, the board of the Castings Corporation was made up in large part of persons who were also directors and principal officers of two corporations that competed with it. In order to avoid Section 8 these directors resigned from the Castings Corporation and were replaced by persons who held lesser offices but were not directors in either of the two other corporations. ${ }^{30}$

27. While it is extremely doubtful that the Supreme Court would hold that this type of interlocking directorship constitutes a per se offense under the Sherman Act, the Court might rule that the existence of the banker-partners on the respective boards of competing manufacturers created a presumption that competition had been restrained as a result of a combination, and shift the burden of proof to the directors.

28. Cf. Purity Extract Cö. v. Iynch, 226 U.S. 192, 204-5 (1912). One of the bills as drafted for consideration during the hearings on the Clayton Act undertools to prevent employees of corporations from being directors in competitors. See Hearings bcfore Committee on Judiciary, H.R., on Trust Legislation, 63rd Cong., 2d Sess. v. 2, p. 942 (1914). Brandeis, one of Wilson's principal advisors on antitrust matters (see Minson, BrandeIs (1946) Part IV, especially c. XXVII), was aware of this problem but considered the "danger" "extremely small." Nevertheless, he advocated a provision which would have eliminated one class of dummy by making it unlawful to have a representative of a director on the board of a competing corporation. He felt, however, that due to the personal influence of Mr. Morgan, his presence on the board, and not that of one of his associates, would usually be necessary to accomplish the results that Congress was seeling to prevent. "You have got to have a big name to conjure with," he said. Hcarings, supre, at 943 .

29. This change was reported by Robert P. Vanderpoel, Financial Editor, in the Chicago Herald-American, Miay 8, 1948.

30. Commenting on this situation the Financial Editor of the Chicago Herald-American stated: "Clearly if it is improper or undesirable from the public point of view for the 
There is another common and important type of interlocking directorship not touched by Section 8 that may be used to eliminate competition: directorships interlocking buyer with seller. A producer of raw materials or a parts manufacturer frequently has one of its directors on the board of its principal customer. An important purpose of this directorship is to insure that the buyer-seller relationship continues without the disturbing effects of competition. In times of shortages of raw materials this situation is reversed; it is the buyer who seeks to have a representative on the board of his steel supplier, for example, to insure his source of supply. These directorships frequently are used to eliminate competition between the supplier and its competitors or the buyer and its competitors. ${ }^{31}$ Yet, since buyer and seller are not competitors, this type of interlocking directorship is not, despite its potential trade-restraining effects, touched by Section 8 . It is no answer to point to the Sherman Act; the restraining effects are subtle and may often derive from a director's persuasive powers rather than from "contract" or "combination."

It is not unfair to conclude that Section 8 , at least as applied to manufacturing corporations, has accomplished none of the objectives sought by its sponsors. ${ }^{32}$ As we have seen, the Section has grave technical defects of which three seem most important. First, the Section fails to prohibit a person who is an employee but not a director of a corporation from serving on the board of a competing corporation. ${ }^{33}$ Second, it places no limitation upon associates in a single banking house from serving as directors of competing corporations so long as each associate serves on the board of a different company. ${ }^{34}$ Third, the Act does not deal with directorships that interlock buyer with seller despite the fact that such directorships are used to eliminate competition. ${ }^{35}$

It would not be an easy task to draft a statute to cover these situations. Supplementary legislation in this field would probably be more effective if it were confined to the larger aggregations of capital. A new statute that would flatly prohibit multiple directorships in corporations over a certain size, and in addition strengthen the existing provisions of Section 8 so as to prohibit the same person from holding office or employment in one corporation as well as a directorship in a competing corporation would seem to remedy the more important defects.

top men of the two companies to sit on the board and direct the policies of the third concern, it cannot be proper or desirable for second position men, dependent for their jobs on the top officials to hold such positions." See note 27 supra.

31. See Means, Interlocking Directorates, in 8 Encrc. of Soc. Scr. 148 (1932).

32. See Corey, House of Morgan 419 (1930).

33. See page 1273 supra.

34. See page 1272 supra.

35. See supra this page. 
The addition of a new paragraph in Section 8 making it unlawful from and after a period, say, of two years from the date of its enactment, for any person to be an officer, director or employee of more than one corporation having total assets in excess of 60 million dollars, whether or not the corporations are competitors, would eliminate most of the directorships that may be used to limit competition and yet are not in violation of Section 8 as presently written. ${ }^{30}$ By using a figure as high as 60 million dollars, the Section would strike at the problem in its most serious aspects ${ }^{37}$ without disturbing the boards of any of the lesser competitors in any given field. Such a statute would affect one or more directors in from 175-200 manufacturing and mining corporations and in from $20-25$ retailing corporations. ${ }^{33}$

One of the premises of the framers of Section $\delta$ was that no person could effectively direct the affairs of more than one giant corporation. ${ }^{53}$ Unless we are to abandon this premise as well as the objectives of Section 8 , legislation along the lines outlined above would seem to be worthy of serious consideration.

36. See Quinn, I Quit MIONster Business 35 (1948).

37. Exceptions to this provision would have to be considered, such as one to authorize an officer, director or employee of a parent to serve its subsidiaries. Possibly also, common carriers, insurance companies, and banking corporations should be excepted. See page 1267 supra.

38. See U.S. Dep't of Conar., Office of Business Econosics, Tadie of Thousajid Largest Mlanufacturing Corporations (based on total assets in 1946), and Mroody's MaNual of INVESTAIENTS (Industrials) (1947).

39. See Brandeis, Other Prople's Mloney, c. X (1914); Douglas, Dircclors Who Do Not Direct, 47 HARV. L. Rev. 1305 (1934). 


\title{
THE YALE LAW JOURNAL
}

\begin{tabular}{lll}
\hline VolUMe 59 & JUNE, 1950 NUMBer 7 \\
\hline
\end{tabular}

\author{
EDITORIAL BOARD \\ DONALD F. TURner \\ Editor-in-Chief \\ Norman Redlich \\ Executive Editor
}

\begin{abstract}
Arnold Hoffacan
LLEWELLYN P. YOUNG

Comment Editors
\end{abstract}

\section{Gerald D. Katcher \\ Case Editor}

Leo P. ARNABoldi, Jr.

Curtis J. Berger

HARRY F. BRAUER

JOHN G. BURNETT

JOEL L. CARR

James C. Cochrane

Paul U. Daniei.

WALTER G. FARR, JR.

HAROLD D. FiELD, JR.

RICHARD M. FitzSTarmons

ROBERT A. FLETCHER

DANIEL J. FREED

Stanley J. Friedman

RICHARD N. GARDNER

\author{
EDWARD N. BENJAMIN \\ Article and \\ Book Review Editor
}

William D. Gins

Richand F. IGL

Note Edilors

Arthur M. Michaelson

Managing Editor

BerNard H. GreENBERG Wilitam E. Hegarty JaMres D. HilborN JoHN S. HOFFINGER JUNIUS HoFrman

Henry L. KIng

ROBERT K. LIFTON

Robert P. Lyons, III

Burke Marshall

Harold J. McComas

Patricta A. McGowan

Donald L. Medlock

Kurt W. MeIchior

Douglas S. Palmier
William R. PerLIK Jerome Preston, JR. JEROME H. REICH William Dili Rogens WHITNEY N. SEYNoUR, JR. Melvin G. Shimis Monroe S. Singer Stuart W. Thayer EuLiot E. VOSE ANDrEW M. WoOd RAYMOND H. YOUNG JOAN ZELDES Edgat: A. Zingian RUCHARD A. ZUNIGA
MARIE McMaHoN

Business Secretary

Subscription price $\$ 5.50$ per year This number, $\$ 1.00$

Canadian Subscription price $\$ 6.00$ per year; Foreign, $\$ 6.25$ per year; for prices on other issues inquire

The Yale Joumal Company, Box 401A Yale Station, New Haven, Connecticul 